\title{
Money Motivates: A Study of Professionals in India
}

\author{
Shilpa Jain ${ }^{1}$, Atul Sharma*2 \\ ${ }^{1}$ Assistant Professor, University School of Management Studies, Guru Gobind Singh Indraprastha University, New Delhi, India \\ 2University School of Management Studies, Guru Gobind Singh Indraprastha University, New Delhi, India
}

Correspondence Author: Atul Sharma, University School of Management Studies, Guru Gobind Singh Indraprastha University, New Delhi, India

Received date: 12 May 2019, Accepted date: 24 June 2019, Online date: 28 June 2019

Copyright: (C) 2019 Shilpa Jain and Atul Sharma. This is an open-access article distributed under the terms of the Creative Commons Attribution License, which permits unrestricted use, distribution, and reproduction in any medium, provided the original author and source are cre dited.

\begin{abstract}
The present research was aimed to study choices of employees and potential employees among different set of motivators, both financial and non-financial in nature. A sample of 237 respondents was chosen from public and private sector organizations pan North India. Different set of motivators considered for the study were broadly categorized in financial and non-financial, and sub categorized into 11 categories, namely, Need Achievement, Need for Recognition, Growth Opportunities, Need for Affiliation, Need for Power, Security Need, Work Life Balance, Fixed pay Monitory Benefits, Variable Pay Monitory Benefits, Regular Indirect Monitory Benefits and Luxury Indirect Monitory Benefits. The study on choices of motivators was done through repeated measure ANOVA in SPSS.

The results show that majority of people prefer Power, Security and Financial Motivators as compared to Affiliation, Recognition, Growth Opportunities, Achievements and Work Life Balance.

The result of the study also reveals that different demographics like age group, gender, sector of employment, Social economic status, Educational background, level of employment have no effect to choice of motivators.
\end{abstract}

Keywords: Motivators, Financial, Non Financial, ANOVA, SPSS, Fixed Pay, Variable Pay, Motivators

\section{INTRODUCTION}

Employee motivation is one of the critical factors at the workplace which determines the performance of the organization. Motivation is psychological, which means that it cannot be forced on the workforce or the employees. An organization may not force it but certainly can provide an environment, culture, compensation structure, growth opportunities, policies and other motivating factors within the organization which can boost up the level of motivation among employees. Motivation is directly related to the needs of an employee. An individual will be highly motivated if the result of his inputs is positively related to his needs, i.e. better the output, higher the need fulfilment.

Many prominent types of research have given theories related to motivation, to name a few, need hierarchy theory of Maslow, acquired need theory by McClelland, Herzberg two factor theory, equity theory of Stacy Adams, Victor Vroom's expectancy theory and goal setting theory of Locke and Latham. These theories were widely accepted and revisited by research scholars. While these theories and concepts were presented in a scientific manner, there is very little discussion of which one proves to be fruitful in providing a better way of solving the problem of motivation within a contemporary definition of job.

Employee motivators can broadly be categorized into 2 segments, financial and non-financial. Incentives, both financial and non-financial, act as a very effective motivator or stimulator because it encourages the employee to improve his level of efficiency and reach the target. Financial or the monetary stimulators can further be classified into many categories, to name a few, Allowances, Profit Sharing, stock options, bonus, commission, performance-linked compensation, retirement benefits, fringe benefits, salary hike, overtime compensation, sponsored education, vouchers, etc. On the other hand, Non-financial stimulators can be categorized into status, career advancements, challenging job, recognition, job security, employee's participation, employee empowerment, learning and development opportunities, good relations with co-workers, work-life balance etc.Starting with Hawthorne studies, researchers have shifted their focus on intrinsic motivators while leaving behind the possible effects of direct and indirect monetary benefits on employee morale.

Consider a situation for your work done well; you are given a choice between

Pair 1

1.Paid International trip with family

Pair 2

2.Involvement in Decision Making

1. Meal Vouchers

2.Compulsory vacations

Which one of the two you will choose from each pair?

Internally we all know that nobody would like to leave paid international trip with family or meal vouchers. Researchers and industry experts may vouch for motivators other than direct financial gains or financial rewards but the fact is MONEY still motivates. There are strong pieces of evidence which emphasize on role of direct or indirect monetary rewards leading to higher levels of satisfaction, engagement and performance.

Leonard [1] has noted that business leaders are more often using incentive programs to motivate employees and get the highest level of performance. Maza [2], Chief People Officer in an article on how to keep employees motivated published by World Economic Forum and Forbes stated that cost cuts, reducing benefits such as food and travel stipends may save money in the short term, but could take a long term clang on employee optimism. Comaford [3] in a Forbes' article also mentioned that the top motivators for generation $\mathrm{Z}$ is money and job security. Haden [4] in an article on twenty five rewards great employees actually love to receive suggested that office perks, free lunches, festival or sporting event tickets, destination holiday on company expenses, adventure day, cruise for two, 
spa day, attending conference of choice, tech accessories like headphones, speakers or smartwatch, movie day are few rewards employees love to receive. Clearly all these rewards are spending money on your employees. In an article on common things amongst 100 best places to work in U.S., Ho [5] mentioned that competitive compensation and great perks and benefits are two important motivators leading to higher engagement and performance of employees.

In an article in Business News Daily, Fallon [6] mentioned that to stay motivated workers need more than a 'pat on the back'. Fallon further noted study conducted by Genesis Associates, wherein the study revealed that 85 percent of the workers surveyed felt more motivated when an incentive was offered. This study also recorded that a company earned 80,000 more British pounds per week on average when they implemented employee reward programs. This survey found that 40 percent respondents cited money as the most motivational followed by a free vacation preferred by 29 percent. A survey conducted by Eventbrite [7] on millennials in the U.S found that $72 \%$ prefer to have exotic experiences than anything else. These exotic experiences can be attending a live concert, themed sports, parties, races etc.

Keeping in mind this importance of direct and indirect financial motivators in the present study was designed to map what motivates working professionals and potential working professionals in Indian organizations. The study included 11 motivators where non-financial motivators are Need Achievement, Need for Recognition, Growth Opportunities, Need for Affiliation, Need for Power, Security Need, Work-Life Balance and financial motivators are Fixed pay Monitory Benefits, Variable Pay Monitory Benefits, Regular Indirect Monitory Benefits and Luxury Indirect Monitory Benefits.

\section{REVIEW OF LITERATURE}

Literature is abreast with the studies indicating the effect of rewards on motivation, job performance, and satisfaction. Here in this study we are quoting few studies conducted in last 6 years.

Belushi and Khan [8] conducted research on impact of monetary incentives on employees' motivation at Shine College of Technology, Oman. Their study included responses of 130 academic and non-academic staff of the institution. The study done by them reveals that employees of the college are motivated only by on duty allowances and salary hike. Non monetary motivators do not stimulate their performance or level of motivation.

Lotanna, Goodfaith and Stella [9] conducted a study to see the effect of monetary incentives on workers' performance for selected firms in Anambra state. They concluded his research with the statement that "if you pick the right people and give them the opportunity to spread their wings, and put out compensation and incentives as the carrier behind it, you almost don't have to manage them". They collected responses from 225 respondents and his analysis clearly says that monetary incentives and benefits play a vital role in improving performance at work.

Mehta [10] conducted a study to see the impact of monetary rewards on employee performance and job satisfaction of professionals working in the insurance sector of Pakistan. He found that monitory rewards have a significant impact on employee performance and job satisfaction. Monitory rewards are found to have $42 \%$ variance in employee performance and $65 \%$ variance in job satisfaction.

Waqas and Saleem [11] conducted research to explore how employee engagement can be improved by offering monitory and non monitory rewards. They also checked the relationship between these rewards and firm performance mediated through employee engagement. The responses were collected from 250 employees working on various levels of management in banks, Universities, textile industries and other private organizations in Faisalabad, Pakistan. The results of the study revealed that monitory and non monitory rewards have a significant effect on employee engagement and firm performance.

Harunavamwe and Kanengoni [12] conducted research to explore the impact of monetary and non monetary rewards on motivation among lower-level employees in selected retail shops on a sample of 50 lower level employees. Findings of this study indicate significant effect of non financial rewards over lowerlevel employees. On the other hand, monetary incentives do not play much role in motivation boost.

Robert [13] in his study of Exploring the sources of motivation states that Perception of the self, one's psychological needs and emotional needs, life goals and aspirations, individual dynamism, culture and impact of social environments are key issues that determine one's ability to self actualize. He talks about how a human resource professionals need to consider different issues related to autonomous motivation and stimulation, controlled motivation, and also motivation as a predictor of performance.

\subsection{Objectives of the study}

\section{RESEARCH METHODOLOGY}

1. To understand the key motivators for the employees today

2. To understand the significant difference among the different motivators

\subsection{Sample}

The sample consisted of 237 respondents, out of which 86 were females and 151 were males working in private and public sector organizations or potential employees located in North India. Out of 237 respondents, 70 were entry-level managers, 125 were middle-level managers, 28 were senior-level managers and 14 were potential employees. Out of 237 respondents, 152 were from age group 18-35, 67 were from age group 36-55 and 18 were from age group of above 55 years. As per the marital status, 153 respondents were married, 82 were unmarried and 2 were divorced. Also, 56 respondents had work experience up to 5 years, 103 respondents had work experience from 6-10 years, 49 respondents had work experience from 11-20 years and 29 respondents had work experience of more than 21 years. Table 1 shows the demographic profile of the respondents.

\subsection{Survey Instrument}

Comprehensive Motivator Schedule: A comprehensive motivator schedule of 11 by 11 matrix was designed to conduct the study. The 11 motivators used for the study were Need Achievement, Need for Recognition, Growth Opportunities, Need for Affiliation, Need for Power, Security Need, Work-Life Balance, Fixed pay Monitory Benefits, Variable Pay Monitory Benefits, Regular Indirect Monitory Benefits and Luxury Indirect Monitory Benefits. The pairwise comparison scaling technique was used to capture the motivators of employees and potential employees. The respondents were asked to consider the 2 motivators in a pair and respond by either rejecting both, if they does not motivate them, select one if one of the motivators from the pair motivates them, and/or select both of the motivators in a pair if both of the motivators are important for them. The number of motivators selected in each category was then calculated and data were tabulated for each respondent on 11 motivators. Table 2 shows the motivators and benefits taken therein for the study.

\section{RESULTS AND DISCUSSIONS}

The means were calculated to understand the key motivators across different genders, age groups, socio-economic status, family income per annum, years of experience in organization and level of management. Repeated Measure ANOVA was used for analyzing the results of the study. Repeated Measures were applied to all the 11 motivators identified and marginal mean for the same was calculated. The pairwise comparison was also studied.

As shown in table 3 and 4, Intercomparison of mean scores of respondents on various motivators with respect to total mean scores depicts that Monitory motivators [Fixed pay monitory benefit (13.43), variable pay monitory benefits (12.88), regular indirect monitory benefits (13.12) and luxury indirect monitory benefits (13.12) ], need for power (13.05), and security need (13.02) are preferred over other motivators like need achievement (7.96), need recognition (10.73), growth opportunities (11.24), need affiliation (10.79) and work-life balance (11.15). On the basis of given scores it can be concluded that employees prefer financial incentives over non-financial ones.

Also, mean scores comparison within the demographics like gender, age group, social economic status, family income, years of work experience, level of management in employment represents similar results. This shows that preferences of all types' employees among motivators are same, irrespective of their gender, age group, social status, social economic status, family income, years of work experience and level of management in employment.

To assess the significant differences in the choice of motivators by respondents, repeated-measures ANOVA was applied. Table 5 shows the results of Mauchley's test of sphericity. The value of this test should be non- significant in order to fulfil the condition that variances of difference amongst various pairs of treatments are not significantly different. The result of this test, in this case, shows non-significant value indicating that the sphericity condition is fulfilled. Further Table 5 shows that the within-subjects effect is significant. This means there is significant difference in the choice of motivators amongst the respondents.

The scrutiny of Table 6 shows that the need for achievement is significantly lower than all other motivators. The results are interesting as well as alarming as it means that challenging work, recognition for achievement and higher responsibility motivates the least. The motivators securing top position are fixed pay 
monetary benefits, variable pay monetary benefits, regular indirect monetary benefits, luxury indirect monetary benefits, job security and need for power. This means incentives like influential position, festive bonus, substantial salary hike, performance allowance amounting at least a month's salary, health insurance, meal vouchers, car on lease, paid higher education, paid national and international trips for self or with family, expensive gifts are acting as motivators today. Table 6 also depicts that monetary benefits along with need for power and security need are significantly higher than other motivators like recognition, affiliation, worklife balance, and growth opportunities. This means that respondents preferred monetary benefits mentioned above, job security and influential position significantly higher than recognition in organization, higher social status, career development, learning and development, involvement in decision making, flexible work schedule and work location near home. Further it is interesting to note that these motivators are same across gender age groups, marital status, level of management and years of experience in organizations.

The results are a clear indication that 'a pat on the back' or 'more challenging work' will not work any more in keeping employees motivated. Rather the employees today look forward to receive incentives in tangible form. Meal Vouchers, movie tickets, national and international trips, bonus, salary hike, paid certifications, insurance, leased vehicle, expensive gifts etc. that makes company spend money on their employees is going to keep employees motivated. In short, MONEY motivates.

\section{CONCLUSION AND MANAGERIAL IMPLICATION}

The results show that employees are majorly driven by financial motivators like fixed pay monitory benefits, variable pay monitory benefits, regular indirect monitory benefits and luxury indirect monitory benefits. Also, they are motivated by power, as it is evident from the study. This study shows evidence that motivators for the majority of population are more or less same, regardless of their demographic profiles, i.e., age, gender, level of employment, social status, work experience. Motivators like need for affiliation and need for achievement is least relevant for employees. This study can be used as a hypothesis for further study of how to keep employees engaged and stimulate their motivation. Organizations can review their engagement and motivational programs and include financial factors to it.

6. LIMITATION OF THE STUDY

The study is limited to North India with a sample size of 237 , hence it cannot be generalised for rest of the region.

Table 1: Demographic profile of the Respondents (237)

\begin{tabular}{|c|c|c|}
\hline \multirow{2}{*}{ Gender } & Male & 151 \\
\cline { 2 - 3 } Level of Employment & Female & 86 \\
\cline { 2 - 3 } & Entry Level & 70 \\
\cline { 2 - 3 } & Middle Level & 125 \\
\cline { 2 - 3 } & Senior Level & 28 \\
\hline \multirow{3}{*}{ Age Group } & Potential Employees & 14 \\
\cline { 2 - 3 } & $18-35$ & 152 \\
\cline { 2 - 3 } & $36-55$ & 67 \\
\hline \multirow{3}{*}{ Marital Status } & M5 plus & 18 \\
\cline { 2 - 3 } & Married & 153 \\
\cline { 2 - 3 } & Unmarried & 82 \\
\hline \multirow{3}{*}{ Work Experience } & Divorced & 2 \\
\cline { 2 - 3 } & $0-5$ years & 56 \\
\cline { 2 - 3 } & $10-20$ years & 103 \\
\cline { 2 - 3 } & $11-20$ years & 49 \\
\hline \multirow{3}{*}{ Sector of Employment } & 20 plus & 29 \\
\cline { 2 - 3 } & Public & 169 \\
\cline { 2 - 3 } & Private \\
\hline
\end{tabular}

Table 2: various benefits taken under various motivators

\begin{tabular}{|c|c|c|c|}
\hline $\begin{array}{c}\text { Serial } \\
\text { Number }\end{array}$ & Motivator & Category & Indicator \\
\hline 1 & Need Achievement & Non - Financial & $\begin{array}{c}\text { Challenging Work, Recognition for Achievement, Higher } \\
\text { Responsibilities }\end{array}$ \\
\hline 2 & Need for Recognition & Non - Financial & Higher Social Status, Recognition in Organization \\
\hline 3 & Growth Opportunities & Non - Financial & Increasing Career Path, Learning and Development Opportunities \\
\hline 4 & Need for Affiliation & Non - Financial & Good Relations with colleagues, Involvement in decision making \\
\hline 5 & Need for Power & Non - Financial & Influential Position, Authoritative Position \\
\hline 6 & Security Need & Non - Financial & Job Security \\
\hline 7 & Work Life Balance & Non - Financial & Flexible work schedule, Location, Compulsory Vacations, \\
\hline 8 & Fixed Pay Monitory Benefits & Financial & Festive bonus, $20-30 \%$ salary hike \\
\hline 9 & $\begin{array}{l}\text { Variable Pay Monitory } \\
\text { Benefits }\end{array}$ & Financial & $\begin{array}{l}\text { Performance allowance up to } 1 \text { month's salary per annum, } \\
\text { Performance allowance more than } 1 \text { months'salary per annum, } \\
\text { performance allowance(irrespective of amount), Overtime pay }\end{array}$ \\
\hline 10 & $\begin{array}{l}\text { Regular Indirect Monitory } \\
\text { Benefits }\end{array}$ & Financial & $\begin{array}{c}\text { Health Insurance, Meal Voucher, Employee stock option plan, car } \\
\text { on lease, paid higher education }\end{array}$ \\
\hline 11 & $\begin{array}{l}\text { Luxury Indirect Monitory } \\
\text { Benefits }\end{array}$ & Financial & $\begin{array}{l}\text { Paid national trips (Individual), paid national trip (Family), paid } \\
\text { international trip(individual), Paid international trip(family), } \\
\text { expensive gifts, external expensive paid certifications }\end{array}$ \\
\hline
\end{tabular}

Table 3: Showing mean scores of Respondents on various motivators with respect to their Gender, Age, Social Economic Status and Family Income p.a.

\begin{tabular}{|c|c|c|c|c|c|c|c|c|c|c|c|c|c|c|}
\hline \multirow[b]{2}{*}{ Motivators } & \multirow[b]{2}{*}{$\begin{array}{l}\text { Total } \\
\text { Mean }\end{array}$} & \multicolumn{2}{|c|}{ Gender } & \multicolumn{3}{|c|}{ Age Group } & \multicolumn{3}{|c|}{ Social Economic Status } & \multicolumn{5}{|c|}{ Family Income } \\
\hline & & $\begin{array}{c}\text { Male } \\
(\mathrm{N}=151)\end{array}$ & $\begin{array}{l}\text { Female } \\
(\mathrm{N}=86)\end{array}$ & $\begin{array}{c}18-35 \\
(\mathrm{~N}=152)\end{array}$ & $\begin{array}{c}36-55 \\
(\mathrm{~N}=67)\end{array}$ & $\begin{array}{l}55 \text { Plus } \\
(\mathrm{N}=18)\end{array}$ & $\begin{array}{c}\text { High } \\
(\mathrm{N}=84)\end{array}$ & $\begin{array}{l}\text { Middle } \\
(\mathrm{N}=133)\end{array}$ & $\begin{array}{c}\text { Low } \\
(\mathrm{N}=20)\end{array}$ & $\begin{array}{c}\text { Upto } 5 \\
\text { lacs } \\
(\mathrm{N}=20)\end{array}$ & $\begin{array}{c}5-10 \text { lacs } \\
(\mathrm{N}=56)\end{array}$ & $\begin{array}{c}10-15 \text { lacs } \\
(\mathrm{N}=123)\end{array}$ & $\begin{array}{c}15-20 \text { lacs } \\
(\mathrm{N}=28)\end{array}$ & $\begin{array}{l}20 \text { lacs } \\
\text { plus } \\
(\mathrm{N}=10)\end{array}$ \\
\hline $\begin{array}{c}\text { Need } \\
\text { Achievement }\end{array}$ & 7.96 & 8.13 & 7.67 & 7.88 & 8.02 & 8.38 & 7.66 & 8.15 & 8 & 7.50 & 8.42 & 8.27 & 6.57 & 6.40 \\
\hline $\begin{array}{c}\text { Need for } \\
\text { Recognition }\end{array}$ & 10.73 & 10.85 & 10.52 & 10.57 & 11.04 & 10.88 & 10.90 & 10.52 & 11.40 & 10.85 & 10.23 & 10.62 & 11.67 & 12 \\
\hline Growth & 11.24 & 11.05 & 11.55 & 11.13 & 11.53 & 11.05 & 10.36 & 11.81 & 11.10 & 9.50 & 12.12 & 11.59 & 9.21 & 11.10 \\
\hline
\end{tabular}


Citation: Shilpa Jain and Atul Sharma, 2019. Money Motivates: A Study of Professionals in India. Journal of Applied Sciences Research., 15(3): 1-5. DOI: 10.22587/jasr.2019.15.3.1

\begin{tabular}{|c|c|c|c|c|c|c|c|c|c|c|c|c|c|c|}
\hline Opportunities & & & & & & & & & & & & & & \\
\hline Need for Power & 13.05 & 12.85 & 13.39 & 12.98 & 13.44 & 12.16 & 12.80 & 13.15 & 13.40 & 12.30 & 13.78 & 12.93 & 12.46 & 13.50 \\
\hline Security Needs & 13.02 & 12.85 & 13.33 & 13.17 & 12.52 & 13.66 & 13.10 & 12.80 & 14.20 & 14.45 & 12.96 & 13.16 & 11.82 & 12.30 \\
\hline $\begin{array}{c}\text { Fixed Pay } \\
\text { Monitory } \\
\text { Benefits }\end{array}$ & 13.43 & 13.58 & 13.15 & 13.40 & 13.71 & 12.55 & 13.66 & 13.15 & 14.25 & 13.45 & 13.75 & 13.19 & 14.25 & 12.20 \\
\hline \begin{tabular}{|c} 
Regular Indirect \\
Monitory \\
Benefits \\
\end{tabular} & 13.12 & 13.27 & 12.86 & 13.26 & 12.65 & 13.66 & 13.22 & 12.97 & 13.65 & 14.15 & 12.57 & 13.04 & 13.53 & 13.90 \\
\hline \begin{tabular}{|c|} 
Luxury Indirect \\
Monitory \\
Benefits
\end{tabular} & 13.96 & 13.84 & 14.17 & 14.05 & 14.23 & 12.16 & 13.95 & 13.81 & 15.00 & 14.25 & 14.39 & 13.58 & 13.53 & 16.80 \\
\hline
\end{tabular}

Table 4: Showing mean scores of respondents on various motivators with respect to their years of work experience and level of management in employment

\begin{tabular}{|c|c|c|c|c|c|c|c|c|}
\hline \multirow{2}{*}{ Motivators } & \multicolumn{3}{|c|}{ Years of work Experience } & \multicolumn{5}{c|}{ Level of Management } \\
\cline { 2 - 11 } & $0-5(\mathrm{~N}=56)$ & $6-10(\mathrm{~N}=103)$ & $11-20(\mathrm{~N}=49)$ & $\begin{array}{c}21 \text { Plus } \\
(\mathrm{N}=29)\end{array}$ & Entry (N=70) & $\begin{array}{c}\text { Middle } \\
(\mathrm{N}=125)\end{array}$ & $\begin{array}{c}\text { Senior }(\mathrm{N}=28) \\
\text { Unemployed } \\
(\mathrm{N}=14)\end{array}$ \\
\hline Need Achievement & 8.08 & 7.83 & 8.24 & 7.72 & 8.44 & 7.82 & 7.67 & 7.42 \\
\hline Need for Recognition & 10.94 & 10.55 & 10.63 & 11.13 & 10.72 & 10.60 & 11.17 & 11.07 \\
\hline Growth Opportunities & 10.75 & 11.46 & 11.48 & 10.96 & 11.64 & 11.48 & 9.67 & 10.21 \\
\hline Need for Affiliation & 9.14 & 11.02 & 11.65 & 11.72 & 10.75 & 10.94 & 11.03 & 9.21 \\
\hline Need for Power & 13.23 & 12.68 & 13.61 & 13.03 & 13.92 & 12.73 & 13.17 & 11.21 \\
\hline Security Needs & 13.69 & 12.66 & 12.48 & 13.96 & 12.98 & 13.16 & 12.21 & 13.71 \\
\hline Work Life Balance & 11.12 & 11.16 & 11.75 & 10.03 & 11.45 & 11.33 & 11.46 & 7.35 \\
\hline $\begin{array}{c}\text { Fixed Pay Monitory } \\
\text { Benefits }\end{array}$ & 13.75 & 13.25 & 13.48 & 13.34 & 13.82 & 13.05 & 13.75 & 14.14 \\
\hline $\begin{array}{c}\text { Variable Pay } \\
\text { Monitory Benefits }\end{array}$ & 13.39 & 11.98 & 13.04 & 14.86 & 11.91 & 13.48 & 12.07 & 14 \\
\hline $\begin{array}{c}\text { Regular Indirect } \\
\text { Monitory Benefits }\end{array}$ & 13.03 & 13 & 13.04 & 13.86 & 13.90 & 12.49 & 13.50 & 14.07 \\
\hline $\begin{array}{c}\text { Luxury Indirect } \\
\text { Monitory Benefits }\end{array}$ & 14.42 & 13.52 & 15.08 & 12.72 & 14 & 13.74 & 14.57 & 14.5 \\
\hline
\end{tabular}

Table 5: Showing Mauchley's Test of Sphericity and Test of Within Subjects for Various Motivators.

\begin{tabular}{|c|c|c|c|c|c|}
\hline \multicolumn{7}{|c|}{ Mauchley's Test of Sphericity } & Sig & \\
\hline Source & Mauchly's W & $\begin{array}{c}\text { Approx. Chi } \\
\text { Square }\end{array}$ & Df & .993 & \\
\hline Within Subjects Effect & .872 & 31.794 & 54 & Sig. \\
\hline \multicolumn{7}{|c|}{ Test of Within Subjects Effects } \\
\hline Source & $\begin{array}{c}\text { Type III Sum of } \\
\text { Squares }\end{array}$ & Df & Mean Square & F & .000 \\
\hline Within Subjects Effect & 7272.07 & 10 & 727.21 & 33.567 & \\
\hline
\end{tabular}

Table 6: Showing Pair Wise Comparisons of Various Motivators and their Significant Differences

\begin{tabular}{|c|c|c|c|c|c|c|c|c|c|c|c|c|}
\hline & & NA & NR & GO & NAF & NP & NS & WLB & FPMB & VPMB & RIMB & LIMB \\
\hline & Means & 7.96 & 10.73 & 11.24 & 10.79 & 13.05 & 13.03 & 11.15 & 13.43 & 12.88 & 13.12 & 13.96 \\
\hline NA & 7.96 & ---- & & & & & & & & & & \\
\hline NR & 10.73 & $\mathrm{SH}$ & ---- & & & & & & & & & \\
\hline GO & 11.24 & SH & $\mathrm{ND}$ & ------ & & & & & & & & \\
\hline NAF & 10.79 & $\mathrm{SH}$ & ND & ND & ----- & & & & & & & \\
\hline $\mathrm{NP}$ & 13.05 & $\mathrm{SH}$ & $\mathrm{SH}$ & $\mathrm{SH}$ & $\mathrm{SH}$ & ----- & & & & & & \\
\hline NS & 13.03 & SH & SH & SH & SH & ND & ---- & & & & & \\
\hline WLB & 11.15 & SH & ND & ND & ND & SL & SL & ---- & & & & \\
\hline FPMB & 13.43 & SH & SH & SH & SH & ND & ND & SH & ---- & & & \\
\hline VPMB & 12.88 & SH & SH & SH & SH & ND & ND & SH & ND & ---- & & \\
\hline RIMB & 13.12 & SH & SH & SH & SH & ND & ND & SH & ND & ND & --- & \\
\hline LIMB & 13.96 & SH & SH & SH & SH & ND & ND & SH & ND & ND & ND & ---- \\
\hline
\end{tabular}

1. Here NA means Need Achievement, NR means Need Recognition, GO means Growth Opportunities, NAF means Need Affiliation, NP means Need for Power, NS means Need for Security, WLB means Work Life Balance, FPMB means Fixed Pay Monetary Benefits, VPMB means

Variable Pay Monetary Benefits, RIMB means Regular Indirect Monetary Benefits, and LIMB means Luxury Indirect Monetary Benefits

2. The significance may be read Row vs Column. For example the column under 'NA' shows that all other variables are significantly higher than Need Achievement.

3. SH means Significantly Higher, SL means Significantly Lower and ND means No Difference 
Citation: Shilpa Jain and Atul Sharma, 2019. Money Motivates: A Study of Professionals in India. Journal of Applied Sciences Research., 15(3): 1-5. DOI: 10.22587/jasr.2019.15.3.1

\section{REFERENCES}

[1] Leonard K, The advantage of using money to motivate employees. 2018. Available at https://smallbusiness.chron.com/advantages-using-money-motivateemployees-22056.html

[2] Maza V, These are the three secrets to motivating your employees. World Economic Forum. June, 08, 2018 Available at https://www.weforum.org/agenda/2018/06/motivating-employees-through-challenging-and-rewarding-times

[3] Comaford C, Why leaders need to embrace employee motivation. Forbes. Jan 20, $2018 . \quad$ Available at https://www.forbes.com/sites/christinecomaford/2018/01/20/why-leaders-need-to-embrace-employee-motivation/\#53cbbf1 f1272

[4] Haden J, 25 rewards that great employees actually love to receive. Inc. 2018. Available at https://www.inc.com/jeff-haden/25-creative-rewards-that-greatemployees-actually-love-to-receive.html

[5] Ho J, Glassdoor's 100 best places to work all have these 8 things in common. Inc. Dec 21, 2017. Available at https://www.inc.com/jackelyn-ho/glassdoors100-best-places-to-work-all-have-these-8-things-in-common.html

[6] Fallon N, Want to boost employee productivity? Offer an incentive. Business News Daily. October 21, 2015 Available at https://www.businessnewsdaily.com/8506-employee-productivity-incentives.html

[7] Eventbrite. Millennials: Fueling the experience economy. Amazon News. 2014 . Available at http://eventbrites3.s3.amazonaws.com/marketing/Millennials_Research/Gen_PR_Final.pdf

[8] Al-Belushi FA, Khan FR. Impact of monetary incentives on employee motivation : Shine College of Technology-Oman: A case Study, International Journal of Management, Innovation \& Entrepreneurial Research 2017:3(1):1-11

[9] Lotanna D, Goodfaith O, Stella M. Effect of monetary incentives on workers' performance: A study of selected firms in Anambra State. International Journal of Current Research. 2016:8(10):40151-40160

[10] Mehta AM. Impact of Monetary Rewards on Employee Performance and Job Satisfaction: An Empirical Study of the Insurance sector of Pakistan. Interdisciplinary Journal of Contemporary Research in Business.2014:5(11):276-283

[11] Waqas Z, Saleem S. The effect of Monetary and Non Monetary Rewards on Employee Engagement and Firm Performance. European Journal of Business and Management. 2014:6(31):73-82

[12] Harunavamwe M, Kanengoni H. The impact of monetary and non monetary rewards on motivation among lower level employees in selected retail shops. African Journal of Business Management. 2013:7(38):3929-3935

[13] Robert EA, Ralph P. Enabling a motivated workforce: Exploring the sources of motivation. Development and learning in Organizations: An international journal. 2012:26(2):7-10 